\title{
T cell responses to SARS-CoV-2 in humans and animals
}

\author{
Sameer-ul-Salam Mattoo and Jinjong Myoung ${ }^{\star}$ \\ Korea Zoonosis Research Institute, Department of Bioactive Material \\ Science and Genetic Engineering Research Institute, Jeonbuk National \\ University, Jeonju 54531, Republic of Korea \\ (Received Dec 1, 2021 / Revised Dec 28, 2021 / Accepted Dec 28, 2021)
}

SARS-CoV-2, the causative agent of COVID-19, first emerged in 2019. Antibody responses against SARS-CoV-2 have been given a lot of attention. However, the armamentarium of humoral and $\mathrm{T}$ cells may have differing roles in different viral infections. Though the exact role of T cells in COVID-19 remains to be elucidated, prior experience with human coronavirus has revealed an essential role of $\mathrm{T}$ cells in the outcomes of viral infections. Moreover, an increasing body of evidence suggests that $\mathrm{T}$ cells might be effective against SARS-CoV-2. This review summarizes the role of $\mathrm{T}$ cells in mouse $\mathrm{CoV}$, human pathogenic respiratory $\mathrm{CoV}$ in general and SARSCoV-2 in specific.

Keywords: SARS-CoV-2, T cell, coronavirus, immune response

\section{Introduction}

Coronaviridae, a family of enveloped single-stranded RNA viruses, consists of two sub-families Orthocoronavirinae and Letovirinae (Pillaiyar et al., 2021; Zhou et al., 2021). Orthocoronavirinae is divided into four genera: Alpha, Beta, Gamma, and Deltacoronavirus. Betacoronavirus includes mouse corona virus (mouse- $\mathrm{CoV}$ or mouse hepatitis virus, $\mathrm{MHV}$ ), severe acute respiratory syndrome coronavirus corona virus 1 (SARS-CoV-1), Middle East respiratory syndrome-CoV (MERS-CoV) and SARS-CoV-2. Mouse-CoV has been adopted as a model to study human CoV (Körner et al., 2020). The infection with the human $\mathrm{CoV}$ is commonly associated with mild respiratory symptoms. However, the emergence of beta subgroup CoV strains, including SARS-CoV-1, MERS-CoV, and SARS-CoV-2, highlights the potential of $\mathrm{CoV}$ to cause severe respiratory and systemic disease (Van Der Hoek et al., 2004; Sariol and Perlman, 2020; Grabherr et al., 2021).

SARS-CoV-1-infected individuals were first reported in 2002 with approximately 8100 reported cases (Peng et al.,

${ }^{*}$ For correspondence. E-mail: jinjong.myoung@jbnu.ac.kr; Tel.: +82-639004055; Fax: +82-63-9004012

Copyright (c) 2022, The Microbiological Society of Korea
2003; Zhao et al., 2003; Sariol and Perlman, 2020). MERS$\mathrm{CoV}$ was identified in 2012 with approximately 2,500 confirmed cases (Zaki et al., 2012). Recently on December 31, 2019, pneumonia caused by an unknown cause was stated to world health organization (WHO), which was later called Coronavirus disease 2019 (COVID-19), of which causative agent is SARS-CoV-2 (Zhou et al., 2020), a highly contagious novel CoV (Hartley et al., 2020). In January 2020, World Health Organization declared COVID-19 an international public health emergency. As of November 29, 2021, more than 260 million people have been infected and more than 5.0 million deaths have been reported worldwide (WHO, 2021). All these three strains, including SARS-CoV-1, MERS-CoV, and SARSCoV-2, can cause severe pneumonia (Cleri et al., 2010; Naeem, 2013; Wang et al., 2020; Yang et al., 2020). However, SARSCoV-1 and MERS-CoV have limited person-to-person transmission, eventually resulting in a lower number of confirmed cases (Sariol and Perlman, 2020), compared with SARS-CoV-2.

Antibody responses induced in patients previously infected with influenza A virus or SARS-CoV-1 tends to be short-lived (Tang et al., 2011). In contrast, memory $\mathrm{T}$ cells can be detected even after 6 years of infection in SARS-CoV-1 recovered patients. An understanding of SARS-CoV-2-specific $\mathrm{T}$ cell responses and more importantly how this particular arm of immune system can be improved to develop more efficient vaccines is the need of the hour.

This review provides a brief summary of roles of $\mathrm{CD} 4^{+}$and $\mathrm{CD}^{+} \mathrm{T}$ cells in mouse-CoV, MERS-CoV and SARS-CoV-1, and then explores roles of different $\mathrm{T}$ cells in SARS-CoV-2 in animal models and humans.

\section{Role of CD4 ${ }^{+}$and $\mathrm{CD}^{+} \mathrm{T}$ Cells in Mouse-CoV}

Mouse-CoV, a group of highly related viral strains, cause a variety of diseases in mice, including enteric disease, hepatitis, respiratory disease, encephalitis, and chronic demyelination depending on viral strain, route of infection, age, immune status, and genetic background of the mice (Weiss and NavasMartin, 2005; Körner et al., 2020). As such, some mouse$\mathrm{CoV}$ s have been adopted as a model to study human $\mathrm{CoV}$ (Körner et al., 2020). For example, MHV-A59 induces acute pneumonia and severe lung injuries in young and old C57BL/ 6 mice, closely resembling acute respiratory distress syndrome (ARDS) caused by MERS-CoV and SARS-CoV- 1 .

Both $\mathrm{CD}^{+}$and $\mathrm{CD} 4^{+} \mathrm{T}$ cells were shown to be required for the clearance of mouse-CoV (MHV-JHM; MHV-4) (Williamson and Stohlman, 1990; Yamaguchi et al., 1991). C57BL/6 
mice, resistant to mouse-CoV, possess dominant mouse-CoV (MHV-1) specific $\mathrm{CD}^{+} \mathrm{T}$ cells both in the breadth and magnitude (Khanolkar et al., 2010), predicting the protective role of $\mathrm{CD}^{+} \mathrm{T}$ cells. Moreover, in $\mathrm{CD} 8^{+} \mathrm{T}$ cell-depleted mice, antibody response plays a minimal role in controlling the infection (Williamson and Stohlman, 1990). CD8 ${ }^{+}$T cells expressing CCR7 sense the expression of CCR7 ligands at the site of inflammation (central nervous system) induced by challenging C57BL/6 intranasally with mouse-CoV (MHV A59) (Cupovic et al., 2016). Moreover, polyfunctional CD8 ${ }^{+} \mathrm{T}$ cells were demonstrated to be critical for the successful elimination of the virus. On the other hand, $\mathrm{CD} 4^{+} \mathrm{T}$ cells provide crucial helper functions in optimizing activation and antiviral properties of $\mathrm{CD}^{+} \mathrm{T}$ cells (Phares et al., 2012) and resistance to mouse-CoV (MHV-3) requires Th1 development (Liu et al., 1998). However, in some strains of mouse-CoV, elevated immune response can be deleterious. For example, in contrast to MHV-A59 and MHV-JHM, MHV-1 induced severe lung damage, which correlated better to the elevated inflammatory immune responses than to viral replication in the lung, predicting that the damage is mainly immunopathological (Leibowitz et al., 2010).

\section{Role of CD4 ${ }^{+}$and $\mathrm{CD8}^{+} \mathrm{T}$ cells in SARS-CoV-1 and MERS-CoV}

Protective role of T cells against SARS-CoV-1 has been analyzed (Zhao et al., 2010; Channappanavar et al., 2014). CD4 ${ }^{+}$ T cell-depleted BALB/c mice show delayed clearance of SARSCoV-1 from the lungs (Chen et al., 2010). Although SARS$\mathrm{CoV}$-1-specific $\mathrm{CD}^{+}{ }^{+} \mathrm{T}$ cells and antibody responses were necessary for complete protection, $\mathrm{CD}^{+} \mathrm{T}$ cell response was critical to protect C57BL/6 mice from lethal SARS-CoV-1 (MA15, mouse-adapted strain) infection (Channappanavar et al., 2014).

Adoptive transfer of serum from vaccinated (Venezuelan equine encephalitis replicon particles expressing MERS-CoV spike [S]-protein, VRP-S) BALB/c mice to naive mice 1-day before challenge significantly reduced the viral load as early as 1-day post-challenge (DPC) (Zhao et al., 2014). However, in contrast to B cell knockout ( $\mu \mathrm{MT})$, T cell knockout (TCRa-/$\mathrm{KO}$ ) or SCID BALB/c mice did not clear MERS-CoV, suggesting a more important role played by $\mathrm{T}$ cells in the protection against viral infection.

SARS-CoV-1-specific T cell responses have been analyzed in peripheral blood mononuclear cells (PBMCs) of human convalescents by using overlapping peptides covering the whole proteome of the virus (Li et al., 2008). These specific $\mathrm{T}$ cells were shown to be essential for the clearance of infected cells, especially in the lungs ( $\mathrm{Gu}$ et al., 2005). In contrast to waning antibody and memory $\mathrm{B}$ cell responses, durable and long-lived memory $\mathrm{T}$ cell responses has been detected in recovered patients (Chen et al., 2005; Peng et al., 2006; Yang et al., 2006, 2007; Fan et al., 2009; Oh et al., 2011; Tang et al., 2011; Da Guan et al., 2015; Ng et al., 2016). A strong MERSCoV S-protein-specific T cell response was described in a patient on the 24th-day post symptom onset (PSO) (Da Guan et al., 2015). Th1-associated cytokines (IL-2 and IFN- $\gamma$ ) have been reported to decrease in a fatal case compared to a patient who survived the infection (Faure et al., 2014), implying the importance of the development of effective $\mathrm{T}$ cell responses in combating the disease.

\section{Role of $\mathrm{CD}^{+}$and $\mathrm{CD}^{+}{ }^{+} \mathrm{T}$ Cells in SARS-CoV-2}

\section{T cell epitopes}

Parts of antigens that are specifically recognized by lymphocytes are called determinants or epitopes. HLA class I and HLA class II restricted epitopes are generally 8 or 11 and 1317 residues long, respectively, although longer and shorter epitopes have also been defined. In the context of SARS-CoV2 , a variety of screening methodologies have been used to identify specific epitopes, including varying size of epitopes, evaluation of responses either directly ex vivo or after an in vitro culture re-stimulation, and various readout types (ELISA, ELISpot, AIM, ICS, tetramer staining, or mass spectrometry) (Grifoni et al., 2021; Pan et al., 2021). A detailed

\begin{tabular}{|c|c|c|}
\hline \multicolumn{3}{|c|}{ SARS-CoV-2 genome } \\
\hline & \multicolumn{2}{|c|}{ ORF1-b } \\
\hline \multicolumn{3}{|c|}{ Dominant epitopes } \\
\hline ORF1 & 2a & PCPIHFYSKWYIRVG ${ }^{k}$ \\
\hline TTDPSFLGR $Y^{\wedge *_{01}}$ & 3a & FYSKWYIRVGARKSA ${ }^{\& \&}$ \\
\hline TTDPSFLGRYM ${ }^{\mathrm{A}^{*} 01}$ & $\begin{array}{l}\text { ALSKGVHFV' } \\
\text { AY }^{* 02}\end{array}$ & SKWYIRVGARKSAPL ${ }^{\mathrm{HLA} A \mathrm{DR}}$ \\
\hline VYIGDPAQL $^{\wedge * 24}$ & VYFLQSINFF & $\mathrm{N}$ \\
\hline IEYPIIGDEL $^{\mathrm{B} * 40}$ & FYYYSRYKNLNSSRYHLA-DR & KTFPPTEPKK ${ }^{A^{*} 03}$ \\
\hline YLITPVHVM $^{B 1501}$ & M & ATEGALNTPK ${ }^{A^{*} 11}$ \\
\hline FYYVWKSYV ${ }^{\mathrm{C} 06: 02}$ & SELVIGAVIL ${ }^{\mathrm{B} * 40}$ & $\begin{array}{l}\text { MEVTPSGTWL }{ }^{\mathrm{B}}+40 \\
\boldsymbol{S} \boldsymbol{P} \boldsymbol{R} \boldsymbol{Y} \boldsymbol{F} \boldsymbol{Y} \boldsymbol{L}^{\mathrm{B} 07: 02}\end{array}$ \\
\hline TLVPQEHYV A ${ }^{* 0201}$ & NRFLYIIKL ${ }^{C^{*} 07}$ & KDGIIWVATEGALNTHLA-DR \\
\hline $\mathrm{S}$ & FVLAAVYRI ${ }^{\Lambda^{*} 0201}$ & GTWLTYTGAIKLDDK ${ }^{\text {HLA-DR }}$ \\
\hline YLQPRTFLL $L^{\wedge * 0201 \mathrm{~S}}$ & YRINWITGGIAIAMA $^{a}$ & RWYFYYLGTGPEAGL ${ }^{\text {HLA-DR }}$ \\
\hline LTDEMIAQY ${ }^{\wedge * 01}$ & KEITVATSRTLSYYK & ASWFTALTQHGKEDL ${ }^{\mathrm{HLA} A-D R}$ \\
\hline QYIKWPWYI & LSYYKLGASQRVAGD $^{\text {HLA-AR }}$ & ASAFFGMSRIGMEVT ${ }^{\text {HLA-DR }}$ \\
\hline ITRFQTLLALHRSYL ${ }^{\mathrm{HLA}-\mathrm{DR}}$ & & IGYYRRATRRIRGGD ${ }^{\text {HLA-DR }}$ \\
\hline CTFEYVSQPFLMDLE" & & LLLLDRLNQLESKMS ${ }^{\text {HLA-DR }}$ \\
\hline
\end{tabular}

Fig. 1. SARS-CoV-2 specific $\mathrm{CD}^{+}$and $\mathrm{CD}^{+} \mathrm{T}$ cell immunodominant epitopes in humans. The dominant epitopes $(\geq 50 \%$ individuals responded to a specific epitope in a particular study, and at least 3 individuals responded) were summarized from multiple studies (Keller et al., 2020; Shomuradova et al., 2020; Nelde et al., 2021; Nielsen et al., 2021; Saini et al., 2021; Tarke et al., 2021). Text in italics and bold represents frequently reported immunodominant epitopes in the literature. ${ }^{\$}$, same epitope showed $33.04 \%$ detection in multimer staining. ", @, , \&, \&\& represent different restricting HLA molecules: \#, DQB1 ${ }^{*} 02: 01, \mathrm{DQB} 1{ }^{*} 02: 02, \mathrm{DQB} 1{ }^{*} 05: 02, \mathrm{DQB} 1{ }^{*} 05: 03, \mathrm{DRB} 1^{*}$ 07:01, $\mathrm{DRB1}^{\star}{ }^{\star 16: 01 ;}{ }^{\circledR}, \mathrm{DQB1}{ }^{*} 02: 02, \mathrm{DQB1}{ }^{\star} 03: 01, \mathrm{DQB} 1^{*} 05: 01$, $\mathrm{DQB1}^{*} 05: 02, \mathrm{DQB1} 1^{*} 05: 03, \mathrm{DQB1} 1^{*} 06: 02, \mathrm{DQB1}^{*} 06: 03, \mathrm{DRB}^{*}$ 07:01, DRB1*10:01, DRB1*12:01, DRB1*13:01, DRB1*14:01, $\mathrm{DRB1}^{\star} 15: 01, \mathrm{DRB1}^{\star} 16: 01{ }^{\wedge}{ }^{\wedge}, \mathrm{DQB}{ }^{\star} 06: 03, \mathrm{DRB} 1^{\star} 03: 01, \mathrm{DRB}^{*}{ }^{*}$ 07:01, DRB1 ${ }^{\star} 14: 01, \mathrm{DRB}^{\star} 14: 06, \mathrm{DRB} 1^{\star} 15: 01, \mathrm{DRB}^{\star} 16: 02$; \&, $\mathrm{DRB}^{*} 08: 02, \mathrm{DRB1}^{\star} 13: 01, \mathrm{DRB} 1^{\star} 15: 01, \mathrm{DRB}^{*} 15: 02, \mathrm{DRB1}^{*}$ 16:01; \&\&, $\mathrm{DQB1}^{*} 06: 01, \mathrm{DRB}^{*} 04: 02, \mathrm{DRB}^{*} 07: 01, \mathrm{DRB1}^{*} 11: 01$, $\mathrm{DRB}^{\star}{ }^{11}: 04, \mathrm{DRB} 1^{\star} 13: 03, \mathrm{DRB} 1^{\star} 14: 01, \mathrm{DRB} 1^{\star} 14: 06, \mathrm{DRB} 1^{*}$ 15:01, DRB1 ${ }^{\star} 15: 02, \mathrm{DRB}^{\star}{ }^{\star} 16: 01, \mathrm{DRB} 1^{\star} 16: 02$. 
review of SARS-CoV-2 human T cell epitopes has been done (Grifoni et al., 2021). Numerous peptides have been reported to be immunodominant in several studies mainly because each study used different subjective criteria of immunodominance. For example, epitopes frequently targeted by $\mathrm{T}$ cells in 6 or more of the 34 participants (Peng et al., 2020), 3 of 13 participants (Grifoni et al., 2021), immune responses induced in $\geq 50 \%$ of tested (Nelde et al., 2021; Saini et al., 2021) and so on. Of note, 3 peptides (open reading frame ORF1; TTDPSFLGRY, S; YLQPRTFLL, nucleocapsid N; SPRWYFYYL) have been reportedly confirmed to be immunodominant in various studies (Grifoni et al., 2021; Wellington et al., 2021). Herein, we briefly summarize the dominant epitopes in SARS-CoV-2 as per the following definition (Nelde et al., 2021; Saini et al., 2021): T cell reactivity to an epitope in $\geq 50 \%$ clinical samples (Fig. 1 ).

In infected individuals, $\mathrm{CD}^{+} \mathrm{T}$ cells have been shown to recognize a range of SARS-CoV-2 antigens (Braun et al., 2020; Grifoni et al., 2020; Le Bert et al., 2020; Lucas et al., 2020; Peng et al., 2020; Thieme et al., 2020; Nelde et al., 2021; Sette and Crotty, 2021). Overall, S, M, and N proteins contain higher numbers of $\mathrm{CD}^{+} \mathrm{T}$ cell epitopes than other viral proteins when assayed on PBMCs from SARS-CoV-2-infected subjects (Grifoni et al., 2020) (Fig. 1A). It is also worthy to note that the response was also directed against other viral proteins as well: nonstructural protein (Nsp)3, Nsp4, ORF3a, ORF8, ORF7a, and Nsp12. Similarly, $\mathrm{CD}^{+} \mathrm{T}$ cells are specific for a range of SARS-CoV-2 antigens (Braun et al., 2020; Gangaev et al., 2020; Grifoni et al., 2020, 2021; Le Bert et al., 2020; Peng et al., 2020; Nelde et al., 2021; Saini et al., 2021) (Fig. 1). In addition, polyfunctional $\mathrm{CD}^{+} \mathrm{T}$ cell responses directed against membrane/nucleocapsid $(\mathrm{M} / \mathrm{N})$-proteins were broader than S protein (Peng et al., 2020). Recently, Pan et al. (2021) identified CD8 ${ }^{+} \mathrm{T}$ cell epitopes in Nsp13 by using mass spectrometry. Of note, Nsp13 peptide-specific CTLs observed in the peripheral blood were able to recognize and lyse SARSCoV-2-infected target cells. Although this study was not extensive, the identified epitopes are highly conserved, immunogenic, and presented by highly prevalent allelotypes. Furthermore, additional epitopes to these and other nonstructural proteins need to be sought, broadening the panel for T cellbased responses which would facilitate the development of effective subunit vaccines and $\mathrm{T}$ cell therapy in the future (Pan et al., 2021).

The pattern of SARS-CoV-2 antigens recognized (evaluated by IFN- $\gamma$ ELISpot) appears to be similar (non-significant difference) during acute, convalescent, and memory phases (Rydyznski Moderbacher et al., 2020). However, interestingly ORF7/8 specific cells may be more selective for acute phase than convalescent phase (Tan et al., 2021). The increased immunogenicity of ORF7/8 during early active phase of infection might be investigated further as the mechanism is not clearly understood, which can be due to accelerated selective expansion, preexisting immunity or some other reasons.

\section{$T$ cells in mice and non-human primates}

Presently different animal models are used to evaluate immune responses and pathogenicity of SARS-CoV-2, including mice expressing human angiotensin I-converting enzyme
2 (hACE2) (Muñoz-Fontela et al., 2020) and mice expressing mRNA-induced hACE2 receptor. Upon infection, hACE2 expressing mice showed $\mathrm{CD} 4^{+} \mathrm{IFN}-\gamma^{+}$and $\mathrm{CD} 8^{+} \mathrm{IFN}-\gamma^{+}$cells in the blood during a prime-boost infection (Hassert et al., 2020). Mice vaccinated with VRPs expressing four structural proteins ( $\mathrm{S}, \mathrm{N}, \mathrm{M}$, or $\mathrm{E}$ ), six accessory proteins (ORF3a, ORF6, ORF7a, ORF8, ORF9b, or ORF9c) or various T cell epitopes, showed that SARS-CoV-2-specific T cells $\left(\mathrm{CD} 4^{+}\right.$and $\mathrm{CD} 8^{+}$ $\mathrm{T}$ cells) were polyfunctional and were able to lyse peptideloaded target cells in vitro (Zhuang et al., 2021). In bronchoalveolar lavage (BAL) dominant $\mathrm{CD}^{+} \mathrm{T}$ cell epitopes were found in N protein and ORF3a in BALB/c (N351-365, ILLNKHIDAYKTFPP) and C57BL/6 mice (ORF3a266-280, EPIYDEPTTTTSVPL), respectively (Zhuang et al., 2021). In contrast, dominant $\mathrm{CD} 8^{+} \mathrm{T}$ cell epitopes were identified in S-protein in both BALB/c (S535-543, KNKCVNFNF) and C57BL/6 (S538-546, CVNFNFNGL) mice. In addition, VRPs expressing only immunodominant $\mathrm{T}$ cell epitopes partially protected the mice in the absence of neutralizing antibodies, hinting on the protective roles of T cells. For example, IFN$\gamma^{+} \mathrm{CD}^{+} / \mathrm{CD}^{+} \mathrm{T}$ cells induced by VRP-N351-365 or VRP-S538-546 vaccination partially protected mice from severe disease and these cells peaked at 8-10 DPC in airway, lung tissue, draining lymph nodes (DLNs) and spleens. On the other hand, in rhesus macaques, $\mathrm{CD} 4^{+}$central memory $\mathrm{T}$ cells were significantly induced at 5 days post re-challenge (DPR) in lymph nodes compared with 5 days post-infection (5 DPI) (Deng et al., 2020). Moreover, activated CD8 ${ }^{+} \mathrm{T}$ cells were significantly increased in blood at 14 DPI and 28 DPI compared to $0 \mathrm{DPI}$, when they were re-challenged. On rechallenging Macaques mulatta, which have been depleted of $\mathrm{CD}^{+} \mathrm{T}$ cells after primary challenge, displayed breakthrough virus shedding in nasal swabs irrespective of CD8a or CD8 $\beta$ depletion. These data demonstrate virus-specific T cells responses play a protective role against the virus (McMahan et al., 2021).

\section{Role of $\mathrm{CD}^{+}$and $\mathrm{CD8}^{+} \mathrm{T}$ cells in humans}

SARS-CoV-2-specific CD4 ${ }^{+} \mathrm{T}$ cells have been shown to differentiate into Th1 and Tfh T cells (Grifoni et al., 2020; Neidleman et al., 2020; Weiskopf et al., 2020). Th1 have antiviral properties and Tfh are specialized in providing help to B cells and thus are pivotal for the development of neutralizing antibodies and memory B cells. While Th2 cells are associated with lung immunopathology in SARS-CoV-1 infection (Deming et al., 2006; Yasui et al., 2008), the dominant cytokine produced by SARS-CoV-2-specific CD4 ${ }^{+} \mathrm{T}$ cells was IFN- $\gamma$ followed by TNF and IL-2 which is a signature of canonical Th1 cell activation (Grifoni et al., 2020; Weiskopf et al., 2020). It was further demonstrated that virus-specific $\mathrm{CD} 4^{+}$and $\mathrm{CD}^{+} \mathrm{T}$ cells were detectable in approximately $100 \%$ and 70-80\% of convalescents (Grifoni et al., 2020; Weiskopf et al., 2020). A similar trend in $\mathrm{CD}^{+}$and $\mathrm{CD} 8^{+} \mathrm{T}$ cells has been seen in acute cases. For example, a study of 10 COVID-19 patients with moderate to severe ARDS, requiring invasive mechanical ventilation, SARS-CoV-2 S-protein-specific CD $4^{+}$ and $\mathrm{CD}^{+} \mathrm{T}$ cells were detected in 10 and 8 patients, respectively (Weiskopf et al., 2020). CD4 ${ }^{+} \mathrm{T}$ cell responses were predominantly Th1 type, however, relatively lower Th2 and Th17 cytokines were also detected. In contrast, Grifoni et 
al. (2020) reported negligible Th2- or Th17-related cytokines in convalescents. In consistent with notion, a study $(n=9)$, which detected SARS-CoV-2-specific T cells with CyTOF, demonstrated that $\mathrm{S}$-specific peripheral Th2 and Th17 cells were not detected in convalescents from mild disease (Neidleman et al., 2020). SARS-CoV-2-specific CD8 ${ }^{+} \mathrm{T}$ cells possess high levels of effector molecules, including IFN- $\gamma$, granzyme B, perforin, and CD107a (Rydyznski Moderbacher et al., 2020; Sekine et al., 2020; Schulien et al., 2021). Early after the emergence of COVID-19, several studies reported an exhausted phenotype, including programmed cell death protein-1 (PD-1) expressing CD ${ }^{+} \mathrm{T}$ cells in COVID-19 patients (De Biasi et al., 2020; Diao et al., 2020; Mahmoudi et al., 2020). However, PD-1, a T cell inhibitory receptor, can be upregulated by T cell receptor-induced activation, which likely reflects activation rather than functional exhaustion (Wherry and Kurachi, 2015; Singer et al., 2016; Rha et al., 2021). Other studies demonstrated that in COVID-19 T cells are activated rather than exhausted (Sekine et al., 2020; Jung et al., 2021; Rha et al., 2021).

T cells in asymptomatic, mild and moderate COVID-19: SARS$\mathrm{CoV}$-2-specific $\mathrm{T}$ cells were functionally superior in asymptomatic individuals compared with symptomatic COVID-19 patients (Le Bert et al., 2021). For example, T cells secreted higher levels of IFN- $\gamma$ and IL-2 and a well-coordinated production of pro-inflammatory (IL-6, TNF- $\alpha$, IL-1 $\beta$ ) and regulatory cytokines (IL-10) than T cells from symptomatic COVID-19 patients. In a recent study, it was shown that preexisting replication transcription complex (RTC: Nsp7, Nsp12, and Nsp13)-specific T cells were enriched and expanded in vivo in seronegative health care workers (SN-HCW, repeatedly remained negative by $\mathrm{PCR}$, antibody binding, and neutralization tests) with abortive infection (confirmed by interferoninducible transcript IFI27 in the blood, a robust early innate signature of SARS-CoV-2) (Swadling et al., 2021). SN-HCW had memory T cells more frequently directed against the RTC, in contrast to structural protein-dominated responses in individuals with detectable infection. By contrast, the group with serologically confirmed infection showed no significant increase in RTC-specific T cells. The presence of virus-specific $\mathrm{CD}^{+} \mathrm{T}$ cells has been associated with better COVID-19 outcomes (Grifoni et al., 2020; Rydyznski Moderbacher et al., 2020; Neidleman et al., 2021; Sette and Crotty, 2021). Compared to S-protein, M/N-specific specific polyfunctional (IFN$\gamma, \mathrm{TNF}$, and IL-2) $\mathrm{CD}^{+} \mathrm{T}$ cells were considerably higher in proportion in mild cases than in severe cases (Peng et al., 2020). Another study showed that SARS-CoV-2 specific CD ${ }^{+}$ and $\mathrm{CD}^{+} \mathrm{T}$ cells both were associated with less severe disease (Rydyznski Moderbacher et al., 2020). Moreover, one COVID-19 patient resolved infection without hospitalization, who had no detectable neutralizing antibodies, but SARS$\mathrm{CoV}$-2-specific $\mathrm{CD} 4^{+}$and $\mathrm{CD} 8^{+} \mathrm{T}$ cells were present. Another study showed that recovered individuals had elevated and increasing numbers of SARS-CoV-2-specific T cells capable of homeostatic proliferation compared with individuals who succumbed (Neidleman et al., 2021).

T cells in severe/critical COVID-19: The number of $\mathrm{CD} 4^{+}$ and $\mathrm{CD}^{+} \mathrm{T}$ cells were lower in severe COVID-19 cases than in moderate cases (Chen et al., 2020). Lower frequencies of IFN- $\gamma$-secreting cells in both early stages (day $1-15$ ) and late stages (day 15-30) were reported in moderate/severe COVID19 patients compared with mild cases (Tan et al., 2021). Moreover, one patient who died had no detectable IFN- $\gamma$-secreting cells until day 26 when stimulated with the different peptide pools. In contrast, studies have also shown that magnitude of T cells was not associated with recovery in critical COVID19 cases (Schub et al., 2020; Weiskopf et al., 2020). SARSCoV-2 specific T cells in severe COVID-19 may have restricted functionality despite high magnitude. For example, the total percentage of SARS-CoV-2-specific polyfunctional $\mathrm{CD} 4{ }^{+} \mathrm{T}$ cells (producing IFN- $\gamma$, TNF- $\alpha$, and IL-2) was significantly lower in ICU patients than convalescents (Schub et al., 2020) (Fig. 3). In contrast, it was also observed that CD $4^{+}$ and $\mathrm{CD}^{+} \mathrm{T}$ cell responses of deceased or critical COVID-19 patients were robust and comparable or even higher than patients with moderate disease (Thieme et al., 2020). A severe infection with a more robust immunogenic environment provided by a higher viral burden and inflammatory bystander activation might lead to a higher magnitude and functionality of the T cell (Thieme et al., 2020).

Marked Lymphopenia is a more prominent feature in patients with severe COVID-19 (Tan et al., 2020; Zhang et al., 2021). It is believed that T cells might be more robustly recruited to the lungs in severe COVID-19. In this context, T cells in lungs and blood might be analyzed in parallel from the same patients at specific time points. Lung residential memory $\mathrm{T}$ cells $\left(\mathrm{T}_{\mathrm{RM}}\right)$ were shown to be critical mediators for protection against secondary viral infections (Schenkel and Masopust, 2014). For example, Influenza A virus-specific lung $\mathrm{T}_{\mathrm{RM}}$ provided potent protection against heterosubtypic influenza challenge, although transient (Pizzolla and Wakim, 2019). In the context of COVID-19 little is known about $\mathrm{T}_{\mathrm{RM}}$. However, studies have reported functional $\mathrm{T}_{\mathrm{RM}}$ in the lung and nasal tissue (Liao et al., 2020; Grau-Expósito et al., 2021; Roukens et al., 2021; Szabo et al., 2021). In COVID-19 patients, airway $\mathrm{T}$ cells characterized by a resident memory T cells phenotype exhibited protective profiles (Szabo et al., 2021). Higher frequencies of these cells were seen in younger individuals who survived the infection compared to older who succumbed (Liao et al., 2020). Additionally, in severe cases of COVID-19, 'immunological misfiring' might result in maladapted immune responses associated with severe clinical outcomes and poor prognosis (Lucas et al., 2020). Moreover, there are indications of alterations in $\mathrm{T}$ cell activation and/or differentiation. Firstly, increased expression levels of exhaustion markers (PD-1, TIM3, LAG3, CTLA4, NKG2A, and CD39) have been reported in patients with COVID-19, particularly in those with severe disease (De Biasi et al., 2020; Diao et al., 2020; Laing et al., 2020; Song et al., 2020; Zheng et al., 2020a, 2020b). However, the expression of these receptors could also indicate recent activation (reviewed by Rha and Shin [2021]). Briefly, Rha et al. (2021) reported that PD-1 expressing S269-specific memory $\mathrm{CD}^{+} \mathrm{T}$ cells were active and not exhausted in acute or convalescent cases, regardless of disease severity. Other studies reported hyper-activated $\mathrm{CD}^{+} \mathrm{T}$ cells with increased cytotoxicity rather than inhibited in severe cases. For example, in mild, severe, and critical cases, peripheral $\mathrm{CD}^{+} \mathrm{T}$ cells decreased in number with a compensatory increase in their cytotoxic potential (evaluated by granzyme A, granzyme $\mathrm{B}$, and perforin expression) (Jiang et 




Fig. 2. A hypothetical model of cellular immune responses to SARS-CoV-2 infection. Finely tuned and effective induction of virus-specific T cells and antibody responses (B cell) leads to an effective clearance of SARS-CoV-2. CD4 ${ }^{+}$and $\mathrm{CD} 8^{+} \mathrm{T}$ cells peak in the acute phase of infection after which the frequency of cells decreases and maintains a stable level in the memory phase. Memory T cells have been reported to be polyfunctional, able to synthesize IFN- $\gamma$, IL-2 or TNF- $\alpha$ on re-stimulation. These cells can supplement memory B cells, which peak for at least 4-8 months before reaching a plateau, for effective formation of plasma cells. The memory phase cells might be strongly responsive to re-infection, ultimately limiting the viral replication and disease progression. Recall response? has not been evaluated yet in the context of COVID-19. Where dotted gray and purple lines represent that the specific memory B and T cells have not been evaluated after 8 and 12 months, respectively.

al., 2020). Another study, which employed single-cell RNA sequencing on nasopharyngeal and bronchial samples, reported that critical disease severity correlated with stronger interaction between epithelial cells and hyper-activated $\mathrm{CD} 8^{+}$ likely contributing to aggravated epithelial cell death (Chua et al., 2020). Neidleman et al. (2021) reported that escalation of activated lung homing bystander $\mathrm{CD} 4^{+} / \mathrm{CD} 8^{+} \mathrm{CXCR} 4^{+}$was associated with fatal COVID-19 outcomes. In contrast, a larger proportion of $\mathrm{CD} 8^{+} \mathrm{T}$ cells with $\mathrm{T}_{\mathrm{RM}}$ characteristics were present in BAL from patients with moderate disease compared to severe COVID-19 (Liao et al., 2020). These studies demonstrate that peripheral blood and lung residential $\mathrm{T}$ cells might function in a coordinated manner against SARS-CoV-2 (Fig. $3)$. However, the exact differential role of T cells in asymptomatic, mild, moderate, and severe/critical cases remains to be elucidated.

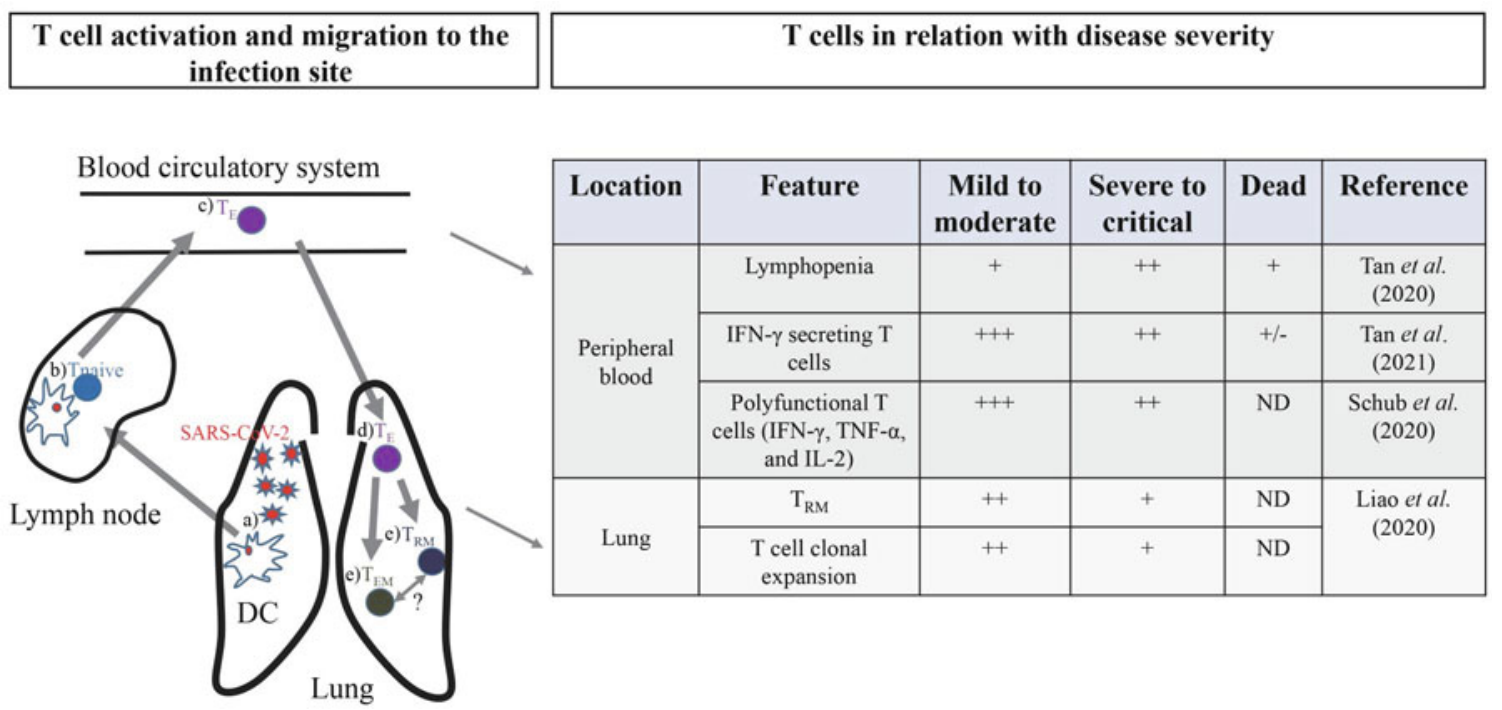

Fig. 3. A proposed model of $\mathrm{T}$ cell responses to SARS-CoV-2 and relation with disease severity. On infection DCs uptake virus/viral particles during their migration to lung-draining lymph node a). Mature and activated DCs activate Tnaive to $T_{E} b$ ) and $c$ ). $T_{E}$ migrate to the lung $d$ ). $T_{E}$ can further differentiate into $\mathrm{T}_{\mathrm{RM}}$ and $\left.\mathrm{T}_{\mathrm{EM}} \mathrm{e}\right)$. Where $\mathrm{ND}=$ not determined, $\mathrm{T}_{\mathrm{E}}=$ effector $\mathrm{T}$ cell, $\mathrm{T}_{\mathrm{EM}}=$ effector memory $\mathrm{T}$ cell and $\mathrm{T}_{\mathrm{RM}}=$ residential memory $\mathrm{T}$ cell. 
Kinetics of T cells in COVID-19: SARS-CoV-2 $\mathrm{T}$ cells have been detected as early as Day 1 PSO (evaluated by MHCtetramer staining) (Schulien et al., 2021) with other studies (assessed by IFN- $\gamma$ producing T cells by ELISpot) reporting 3-5 days PSO (Moderbacher et al., 2020; Tan et al., 2021). An early induction ( $<10$ days PSO) of SARS-CoV-2-specific $\mathrm{T}$ cells has been reported in milder cases (Tan et al., 2021). $\mathrm{CD}^{+}$and $\mathrm{CD}^{+} \mathrm{T}$ cells show differential kinetics in the contraction phase: $\mathrm{CD} 8^{+} \mathrm{T}$ cells display signs of progressive reduction after viral clearance while $\mathrm{CD} 4^{+} \mathrm{T}$ cells were more stable during 1-3 months PSO (Rydyznski Moderbacher et al., 2020). However, after an initial contraction phase (Tan et al., 2021), polyfunctional (IFN- $\gamma$, IL-2, and/or TNF- $\alpha$-secreting) $\mathrm{T}$ cells remained detectable for at least 6-12 months PSO (Breton et al., 2021; Cohen et al., 2021; Dan et al., 2021; Le Bert et al., 2021; Lu et al., 2021). Polyfunctional T cells have been observed more frequently in convalescents with milder symptoms while severe and critical patients tend to have restricted functional T cells (1-2 months PSO) (Schub et al., 2020).

On re-infection, memory $\mathrm{T}$ and $\mathrm{B}$ cells can be responsive and supplement each other in the viral clearance (Fig. 2). Immunological memory provides rapid protection against re-infection. Memory T cells can be classified as $\mathrm{T}$ residential memory $\left(\mathrm{T}_{\mathrm{RM}}, \mathrm{CCR} 7^{+} \mathrm{CD} 45 \mathrm{RA}\right.$, reside at the site of infection), $\mathrm{T}$ central memory $\left(\mathrm{T}_{\mathrm{CM}}, \mathrm{CCR} 7^{+} \mathrm{CD} 45 \mathrm{RA}{ }^{-}\right.$, circulate in the blood and home in lymphoid organs), $\mathrm{T}$ effector memory ( $\mathrm{T}_{\mathrm{EM}}$, CCR7 ${ }^{-} \mathrm{CD} 45 \mathrm{RA}$, circulate in the blood and home in non-lymphoid organs) and effector memory re-expressing CD45RA ( $\mathrm{T}_{\mathrm{EMRA}}, \mathrm{CCR}^{-} \mathrm{CD} 45 \mathrm{RA}^{+}$, circulate in the blood ) (Seder and Ahmed, 2003; Tian et al., 2017; Gray et al., 2018; Martin and Badovinac, 2018). In contrast to $\mathrm{T}_{\mathrm{RM}}$, which might be playing an important role in the clearance of SARS-CoV-2 (discussed in section ' $\mathrm{T}$ cells in asymptomatic, mild and moderate COVID-19'), several studies have been performed on peripheral blood $\mathrm{T}$ cell subsets in COVID-19 individuals. These cells are composed of naive (Tnaive), $\mathrm{T}_{\mathrm{CM}}, \mathrm{T}_{\mathrm{EM}}$, and $\mathrm{T}_{\text {EMrA }}$ phenotypes (Breton et al., 2021; Cohen et al., 2021; Dan et al., 2021; Lu et al., 2021; Schulien et al., 2021), and early $\left(\mathrm{CD} 27^{+} \mathrm{CD} 28^{+}\right)$or intermediate $\left(\mathrm{CD} 27^{+} \mathrm{CD} 28^{-}\right)$differentiation phenotypes (Peng et al., 2020). The presence of a minor Tnaive subset fraction (median, 3.9\%) of $\mathrm{CD}^{+} \mathrm{T}$ cells supports the notion that most of these cells have been efficiently primed during the infection (Schulien et al., 2021). Another study reported that SARS-CoV-2-specific MHC-I tetramer ${ }^{+} \mathrm{CD}^{+} \mathrm{T}$ cells exhibited an early differentiated memory phenotype $\left(\mathrm{CCR} 7^{+} \mathrm{CD} 127^{+} \mathrm{CD} 45 \mathrm{RA}^{-/+} \mathrm{TCF} 1^{+}\right)$in convalescents (Sekine et al., 2020). This phenotype of cells was associated with stem cell-like properties. Of note, stem celllike memory $\mathrm{T}$ cells $\left(\mathrm{T}_{\mathrm{SCM}}\right)$ have the ability of self-renewal and multipotency to repopulate the broad spectrum of memory and effector T cell subsets (Gattinoni et al., 2011, 2017). Moreover, $\mathrm{T}_{\mathrm{SCM}}\left(\mathrm{CCR} 7^{+} \mathrm{CD} 45 \mathrm{RA}^{+} \mathrm{CD} 95^{+}\right)$cells in COVID-19 convalescents displayed poly-functionality and proliferation capacity during a 10-month follow-up period (Jung et al., 2021), suggesting that these memory T cells might be longliving. Moreover, in this study SARS-CoV-2-specific T cell memory was maintained regardless of disease severity. In a study comparing $\mathrm{T}$ cell responses in prolonged SARS-CoV2 positive $(\mathrm{PP})$ clinically recovered (CR) and healthy donors, the $\mathrm{CD} 8^{+} \mathrm{T}_{\mathrm{E}} / \mathrm{T}_{\mathrm{EM}}$ cell frequency and number was significantly lower in PP compared with CR patients (Yang et al., 2021). The suppressed $\mathrm{CD}^{+} \mathrm{T}$ cell differentiation in PP was likely to be associated with prolonged infection, demonstrating the importance of $\mathrm{CD}^{+} \mathrm{T}$ cells in virus clearance. Moreover, SARS-CoV-2 $\mathrm{N}$ protein-specific IFN- $\gamma^{+} \mathrm{T}$ cell response in the PP cohort was significantly weaker than that in the CR cohort.

Whether $\mathrm{T}$ cell kinetics vary among SARS-CoV-2 strains, and different proteins/epitopes induce different $\mathrm{T}$ cell kinetics remains to be evaluated. As described previously, Tan et al. (2021) reported that in mild cases, T cells specific for ORF7 and OFR8 were induced early and were more robustly detected in the early phase of infection. Nevertheless, these claims need to be evaluated in a larger population to reach a sound conclusion.

Summary of different methodologies used to evaluate the $\mathrm{T}$ cells in acute and convalescent individuals having asymptomatic, mild moderate severe or critical COVID-19 has been provided in Table 1.

T cells in vaccinated individuals: In mRNA (Sahin et al., 2020), adenovirus vector-based vaccines (Swanson et al., 2021), and protein subunit vaccines (Keech et al., 2020) a Th1-skewed response with little to no Th2 cytokine profile has been detected, while $\mathrm{Tfh}$ and $\mathrm{CD} 8^{+} \mathrm{T}$ cells have also been detected in vaccinated individuals (Sahin et al., 2020; Koutsakos et al., 2021; Painter et al., 2021; Sette and Crotty, 2021). T cell responses in COVID-19 mRNA vaccinees showed memory phenotypes, with a preference for $\mathrm{T}_{\mathrm{CM}}$ and $\mathrm{T}_{\mathrm{EM}}$ for $\mathrm{CD} 4^{+}$and $\mathrm{T}_{\mathrm{EM}}$ and $\mathrm{T}_{\mathrm{EMRA}}$ for $\mathrm{CD} 8^{+} \mathrm{T}$ cells (Guerrera et al., 2021; Tarke et al., 2021), which were detectable for at least 6-months-PSO (Guerrera et al., 2021). Moreover, vaccination also induced $\mathrm{CD}^{+}$and $\mathrm{CD}^{+} \mathrm{T}_{\text {SCM }}$. $\mathrm{T}$ cell responses induced by vaccines are supposed to recognize SARS-CoV-2 variants (Geers et al., 2021; Tarke et al., 2021). For example, the $\mathrm{CD}^{+} / \mathrm{CD}^{+}$ $\mathrm{T}$ cell reactivity in vaccinated individuals was not significantly reduced by mutations in B.1.1.7 and P.1 (Jordan et al., 2021; Tarke et al., 2021). However, decreases of $14 \%$ and $22 \%$ were observed with the B.1.351 S-pools for $\mathrm{CD}^{+}$and $\mathrm{CD} 8^{+} \mathrm{T}$ cells, respectively. As discussed somewhere, multiple $\mathrm{T}$ cell epitopes are distributed across viral proteins including structural, nonstructural, and accessory proteins which makes evasion of viruses from $\mathrm{T}$ cell responses more difficult than neutralizing antibody responses (Noh et al., 2021). The vast majority of $\mathrm{CD}^{+}$and $\mathrm{CD}^{+} \mathrm{T}$ cell epitopes were not affected by mutations found in different SARS-CoV-2 variants (Tarke et al., 2021). Neutralizing antibodies, on the other hand, tend to target a restricted protein domain exposed on the virus surface, such as the S-protein of SARS-CoV-2. Currently, mRNA, adenovirus vector-based, and protein subunit vaccines rely on the S-protein as immunogen. Vaccines with multiple targets, including but not limited to the SARS-CoV-2 S-protein, are currently being developed and should elicit broad $\mathrm{T}$ cell responses (Noh et al., 2021). These include a) protein-based vaccine, incorporating multiple $\mathrm{CD} 4^{+}$and $\mathrm{CD} 8^{+} \mathrm{T}$ cell epitopes selected from SARS-CoV-2 M, S2, and N proteins (NCT04683224); b) DNA platform vaccine, expressing S and $\mathrm{N}$ proteins (NCT04715997) or S and ORF3a proteins (NCT04673149); c) adenovirus vector vaccines expressing $\mathrm{S}$ and $\mathrm{N}$ proteins (NCT04843722 and NCT04563702); d) chim- 


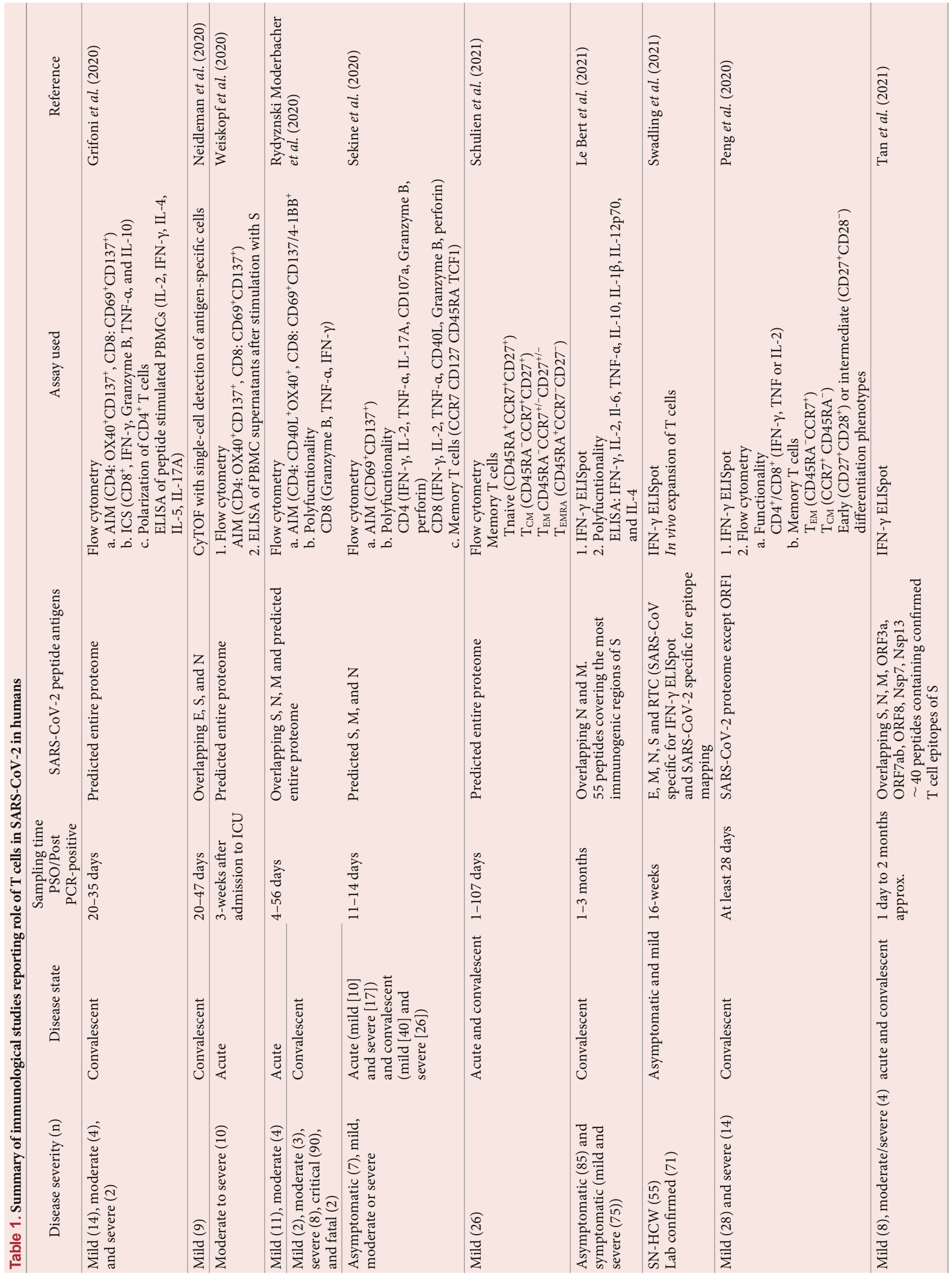




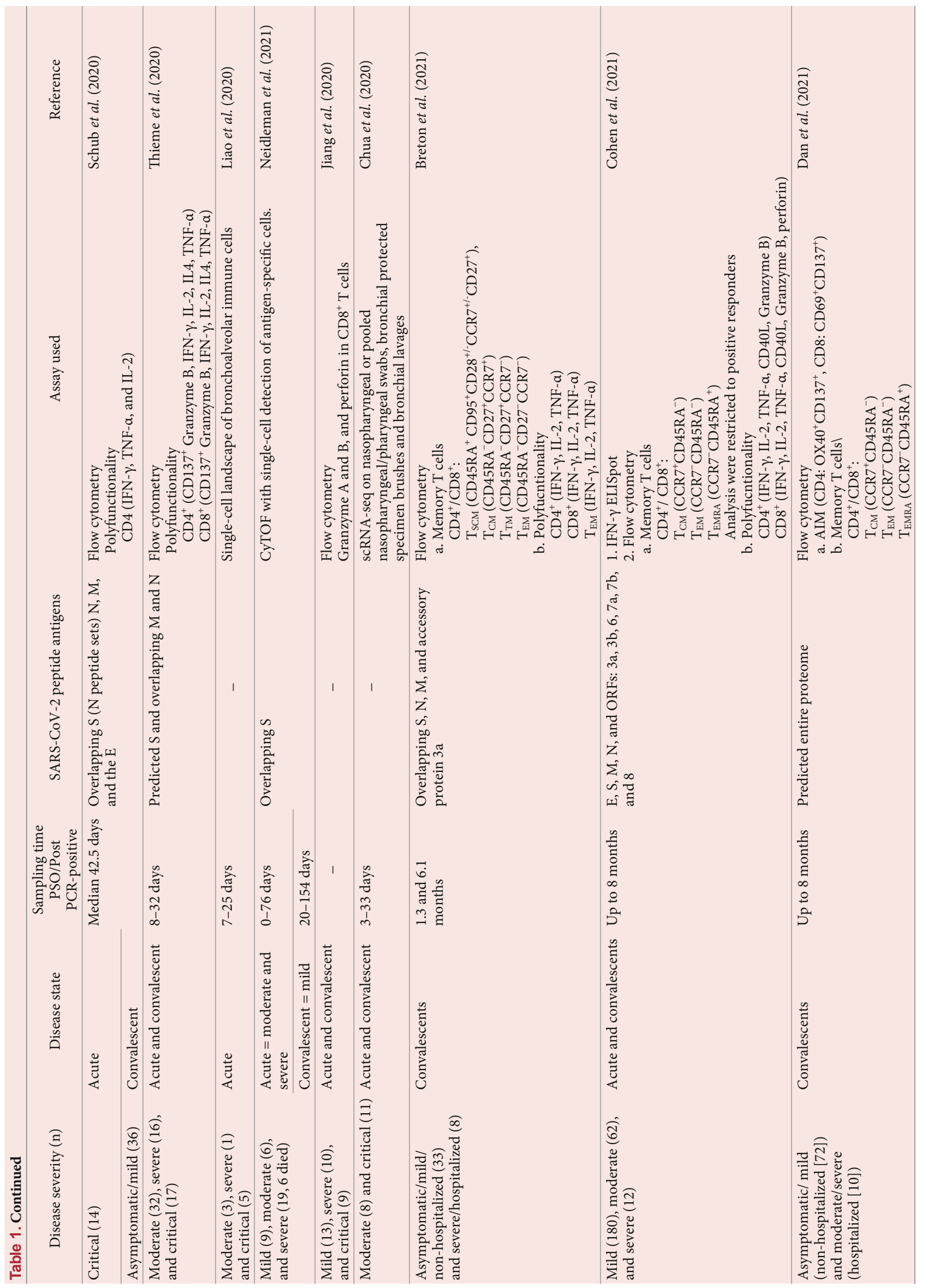




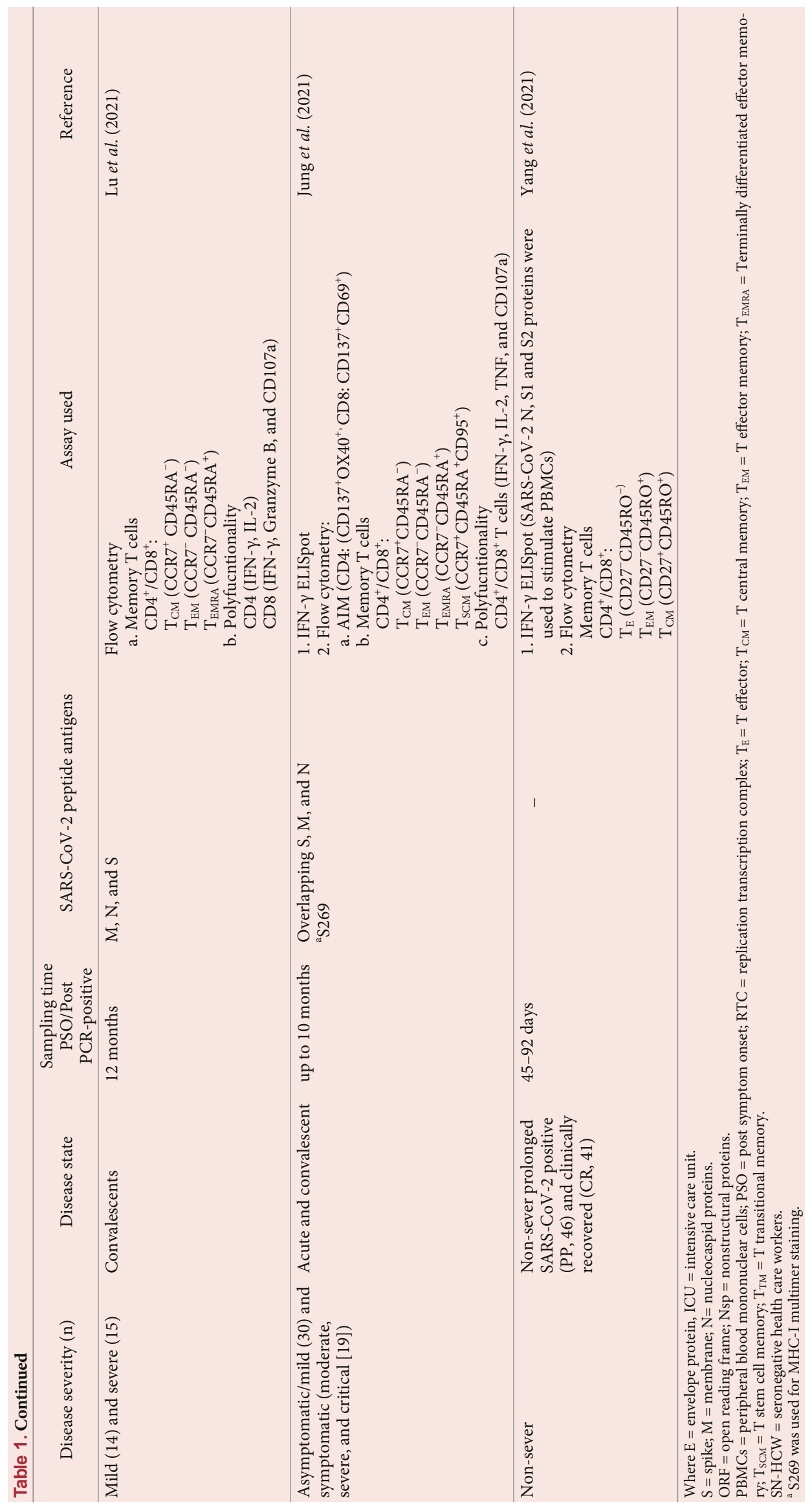


panzee adenovirus and self-amplifying mRNA vector vaccines expressing S-protein and additional $\mathrm{T}$ cell epitopes (NCT04776317); e) synthetic modified viral vectored vaccine, encoding S and N proteins (NCT04977024); f) peptide vaccines, using $\mathrm{CD}^{+}{ }^{+}$or $\mathrm{CD}^{+} \mathrm{T}$ cell epitopes (NCT04885361 and NCT04954469).

\section{Future Perspective and Concluding Remarks}

Currently, most of the vaccines adopt the S-protein as immunogen for inducing immune responses against SARSCoV-2 in humans (Corbett et al., 2020; Sahin et al., 2020; Liu et al., 2021). However, $\mathrm{CD}^{+} \mathrm{T}$ cell immunodominant epitopes are also found in ORF1 and ORF3, their inclusion in the vaccines needs to be considered (Swadling et al., 2021; Wellington et al., 2021). Moreover, in humans recovered from mild cases, multiple cytokine (IFN- $\gamma$, TNF or IL-2)-producing $\mathrm{CD}^{+} \mathrm{T}$ cells specific for $\mathrm{M} / \mathrm{N}$-proteins were higher in proportion compared with S-protein-specific cells, necessitating inclusion of $\mathrm{M} / \mathrm{N}$-proteins/epitopes for future vaccine studies (Peng et al., 2020).

A large body of evidence has been accumulated on the role of $\mathrm{T}$ cells in coronavirus infections both in mice and in humans. However, the role of $\mathrm{T}$ cells in combating SARSCoV-2 needs to be further investigated in depth in animal models due to difficulty and scarcity of human tissue samples for analysis. Additionally, whether the presence of SARSCoV-2-specific $\mathrm{T}$ cells forebode a bad prognosis in severe and critical cases need to be carefully investigated.

Currently, cell-mediated immune responses against SARS$\mathrm{CoV}-2$ have been studied mostly in peripheral blood. As such, detailed analysis of the role(s) of tissue resident $\mathrm{T}$ cells in the context of SARS-CoV-2 infections would shed light on their relative importance in viral clearance and/or pathology.

\section{Acknowledgements}

This research was supported by Basic Science Research Program through the National Research Foundation of Korea (NRF) funded by the Ministry of Education (2017R1A6A1A03015876).

\section{Conflict of Interest}

The authors declare that there are no conflicts of interest.

\section{References}

Braun, J., Loyal, L., Frentsch, M., Wendisch, D., Georg, P., Kurth, F., Hippenstiel, S., Dingeldey, M., Kruse, B., Fauchere, F., et al. 2020. SARS-CoV-2-reactive $\mathrm{T}$ cells in healthy donors and patients with COVID-19. Nature 587, 270-274.

Breton, G., Mendoza, P., Hägglöf, T., Oliveira, T.Y., Schaefer-Babajew, D., Gaebler, C., Turroja, M., Hurley, A., Caskey, M., and Nussenzweig, M.C. 2021. Persistent cellular immunity to SARSCoV-2 infection. J. Exp. Med. 218, e20202515.

Channappanavar, R., Fett, C., Zhao, J., Meyerholz, D.K., and Perl- man, S. 2014. Virus-specific memory CD8 T cells provide substantial protection from lethal severe acute respiratory syndrome coronavirus infection. J. Virol. 88, 11034-11044.

Chen, H., Hou, J., Jiang, X., Ma, S., Meng, M., Wang, B., Zhang, M., Zhang, M., Tang, X., Zhang, F., et al. 2005. Response of memory $\mathrm{CD}^{+} \mathrm{T}$ cells to severe acute respiratory syndrome (SARS) coronavirus in recovered SARS patients and healthy individuals. $J$. Immunol. 175, 591-598.

Chen, J., Lau, Y.F., Lamirande, E.W., Paddock, C.D., Bartlett, J.H., Zaki, S.R., and Subbarao, K. 2010. Cellular immune responses to severe acute respiratory syndrome coronavirus (SARS-CoV) infection in senescent BALB/c Mice: $\mathrm{CD}^{+} \mathrm{T}$ cells are important in control of SARS-CoV infection. J. Virol. 84, 1289-1301.

Chen, G., Wu, D., Guo, W., Cao, Y., Huang, D., Wang, H., Wang, T., Zhang, X., Chen, H., Yu, H., et al. 2020. Clinical and immunological features of severe and moderate coronavirus disease 2019. J. Clin. Invest. 130, 2620-2629.

Chua, R.L., Lukassen, S., Trump, S., Hennig, B.P., Wendisch, D., Pott, F., Debnath, O., Thürmann, L., Kurth, F., Völker, M.T., et al. 2020. COVID-19 severity correlates with airway epithelium-immune cell interactions identified by single-cell analysis. Nat. Biotechnol. 38, 970-979.

Cleri, D.J., Ricketti, A.J., and Vernaleo, J.R. 2010. Severe acute respiratory syndrome (SARS). Infect. Dis. Clin. North Am. 24, 175-202.

Cohen, K.W., Linderman, S.L., Moodie, Z., Czartoski, J., Lai, L., Mantus, G., Norwood, C., Nyhoff, L.E., Edara, V.V., Floyd, K., et al. 2021. Longitudinal analysis shows durable and broad immune memory after SARS-CoV-2 infection with persisting antibody responses and memory B and T cells. Cell Rep. Med. 2, 100354.

Corbett, K.S., Edwards, D.K., Leist, S.R., Abiona, O.M., BoyogluBarnum, S., Gillespie, R.A., Himansu, S., Schäfer, A., Ziwawo, C.T., DiPiazza, A.T., et al. 2020. SARS-CoV-2 mRNA vaccine design enabled by prototype pathogen preparedness. Nature 586, 567-571.

Cupovic, J., Onder, L., Gil-Cruz, C., Weiler, E., Caviezel-Firner, S., Perez-Shibayama, C., Rülicke, T., Bechmann, I., and Ludewig, B. 2016. Central nervous system stromal cells control local $\mathrm{CD}^{+}$ $\mathrm{T}$ cell responses during virus-induced neuroinflammation. Immunity 44, 622-633.

Da Guan, W., Mok, C.K.P., Chen, Z.L., Feng, L.Q., Li, Z.T., Huang, J.C., Ke, C.W., Deng, X., Ling, Y., Wu, S.G., et al. 2015. Characteristics of traveler with Middle East respiratory syndrome, China, 2015. Emerg. Infect. Dis. 21, 2278-2280.

Dan, J.M., Mateus, J., Kato, Y., Hastie, K.M., Yu, E.D., Faliti, C.E., Grifoni, A., Ramirez, S.I., Haupt, S., Frazier, A., et al. 2021. Immunological memory to SARS-CoV-2 assessed for up to 8 months after infection. Science 371, eabf4063.

De Biasi, S., Meschiari, M., Gibellini, L., Bellinazzi, C., Borella, R., Fidanza, L., Gozzi, L., Iannone, A., Tartaro, D.L., Mattioli, M., et al. 2020. Marked T cell activation, senescence, exhaustion and skewing towards TH17 in patients with COVID-19 pneumonia. Nat. Commun. 11, 3434.

Deming, D., Sheahan, T., Heise, M., Yount, B., Davis, N., Sims, A., Suthar, M., Harkema, J., Whitmore, A., Pickles, R., et al. 2006. Vaccine efficacy in senescent mice challenged with recombinant SARS-CoV bearing epidemic and zoonotic spike variants. PLoS Med. 3, 2359-2375.

Deng, W., Bao, L., Liu, J., Xiao, C., Liu, J., Xue, J., Lv, Q., Qi, F., Gao, H., Yu, P., et al. 2020. Primary exposure to SARS-CoV-2 protects against reinfection in rhesus macaques. Science 369, 818-823.

Diao, B., Wang, C., Tan, Y., Chen, X., Liu, Y., Ning, L., Chen, L., Li, M., Liu, Y., Wang, G., et al. 2020. Reduction and functional exhaustion of T cells in patients with coronavirus disease 2019 (COVID-19). Front. Immunol. 11, 827. 
Fan, Y.Y., Huang, Z.T., Li, L., Wu, M.H., Yu, T., Koup, R.A., Bailer, R.T., and Wu, C.Y. 2009. Characterization of SARS-CoV-specific memory $\mathrm{T}$ cells from recovered individuals 4 years after infection. Arch. Virol. 154, 1093-1099.

Faure, E., Poissy, J., Goffard, A., Fournier, C., Kipnis, E., Titecat, M., Bortolotti, P., Martinez, L., Dubucquoi, S., Dessein, R., et al. 2014. Distinct immune response in two MERS-CoV-infected patients: Can we go from bench to bedside? PLoS ONE 9, e88716.

Gangaev, A., Ketelaars, S.L., Patiwael, S., Dopler, A., Isaeva, O.I., Hoefakker, K., De Biasi, S., Mussini, C., Guaraldi, G., Girardis, M., et al. 2020. Abstract S05-01: Profound CD8 T-cell responses towards SARS-CoV-2 OFR1ab in COVID-19 patients. AACR Virtual Meeting: COVID-19 and Cancer 26, S05-01-S05-01.

Gattinoni, L., Lugli, E., Ji, Y., Pos, Z., Paulos, C.M., Quigley, M.F., Almeida, J.R., Gostick, E., Yu, Z., Carpenito, C., et al. 2011. A human memory $\mathrm{T}$ cell subset with stem cell-like properties. Nat. Med. 17, 1290-1297.

Gattinoni, L., Speiser, D.E., Lichterfeld, M., and Bonini, C. 2017. T memory stem cells in health and disease. Nat. Med. 23, 18-27.

Geers, D., Shamier, M.C., Bogers, S., den Hartog, G., Gommers, L., Nieuwkoop, N.N., Schmitz, K.S., Rijsbergen, L.C., van Osch, J.A., Dijkhuizen, E., et al. 2021. SARS-CoV-2 variants of concern partially escape humoral but not T cell responses in COVID-19 convalescent donors and vaccine recipients. Sci. Immunol. 6 , eabj1750.

Grabherr, S., Ludewig, B., and Pikor, N.B. 2021. Insights into coronavirus immunity taught by the murine coronavirus. Eur. J. Immunol. 51, 1062-1070.

Grau-Expósito, J., Sánchez-Gaona, N., Massana, N., Suppi, M., Astorga-Gamaza, A., Perea, D., Rosado, J., Falcó, A., Kirkegaard, C., Torrella, A., et al. 2021. Peripheral and lung resident memory T cell responses against SARS-CoV-2. Nat. Commun. 12, 3010.

Gray, J.I., Westerhof, L.M., and MacLeod, M.K.L. 2018. The roles of resident, central and effector memory CD4 T-cells in protective immunity following infection or vaccination. Immunology 154, 574-581.

Grifoni, A., Sidney, J., Vita, R., Peters, B., Crotty, S., Weiskopf, D., and Sette, A. 2021. SARS-CoV-2 human T cell epitopes: adaptive immune response against COVID-19. Cell Host Microbe 29, 1076-1092.

Grifoni, A., Weiskopf, D., Ramirez, S.I., Mateus, J., Dan, J.M., Moderbacher, C.R., Rawlings, S.A., Sutherland, A., Premkumar, L., Jadi, R.S., et al. 2020. Targets of T cell responses to SARSCoV-2 coronavirus in humans with COVID-19 disease and unexposed individuals. Cell 181, 1489-1501. e1415.

Gu, J., Gong, E., Zhang, B., Zheng, J., Gao, Z., Zhong, Y., Zou, W., Zhan, J., Wang, S., Xie, Z., et al. 2005. Multiple organ infection and the pathogenesis of SARS. J. Exp. Med. 202, 415-424.

Guerrera, G., Picozza, M., D’Orso, S., Placido, R., Pirronello, M., Verdiani, A., Termine, A., Fabrizio, C., Giannessi, F., Sambucci, M., et al. 2021. BNT162b2 vaccination induces durable SARSCoV-2 specific T cells with a stem cell memory phenotype. Sci. Immunol. 6, eabl5344.

Hartley, G.E., Edwards, E.S.J., Aui, P.M., Varese, N., Stojanovic, S., McMahon, J., Peleg, A.Y., Boo, I., Drummer, H.E., Hogarth, P.M., et al. 2020. Rapid generation of durable B cell memory to SARS-CoV-2 spike and nucleocapsid proteins in COVID-19 and convalescence. Sci. Immunol. 5, eabf8891.

Hassert, M., Geerling, E., Stone, E.T., Steffen, T.L., Feldman, M.S., Dickson, A.L., Class, J., Richner, J.M., Brien, J.D., and Pinto, A.K. 2020. mRNA induced expression of human angiotensin-converting enzyme 2 in mice for the study of the adaptive immune response to severe acute respiratory syndrome coronavirus 2. PLoS Pathog. 16, el009163.

Jiang, Y., Wei, X., Guan, J., Qin, S., Wang, Z., Lu, H., Qian, J., Wu, L., Chen, Y., Chen, Y., et al. 2020. COVID-19 pneumonia: CD8 ${ }^{+}$ $\mathrm{T}$ and NK cells are decreased in number but compensatory in- creased in cytotoxic potential. Clin. Immunol. 218, 108516.

Jordan, S.C., Shin, B.H., Gadsden, T.A.M., Chu, M., Petrosyan, A., Le, C.N., Zabner, R., Oft, J., Pedraza, I., Cheng, S., et al. 2021. T cell immune responses to SARS-CoV-2 and variants of concern (Alpha and Delta) in infected and vaccinated individuals. Cell. Mol. Immunol. 18, 2554-2556.

Jung, J.H., Rha, M.S., Sa, M., Choi, H.K., Jeon, J.H., Seok, H., Park, D.W., Park, S.H., Jeong, H.W., Choi, W.S., et al. 2021. SARSCoV-2-specific T cell memory is sustained in COVID-19 convalescent patients for 10 months with successful development of stem cell-like memory T cells. Nat. Commun. 12, 4043.

Keech, C., Albert, G., Cho, I., Robertson, A., Reed, P., Neal, S., Plested, J.S., Zhu, M., Cloney-Clark, S., and Zhou, H. 2020. Phase 1-2 trial of a SARS-CoV-2 recombinant spike protein nanoparticle vaccine. N. Engl. J. Med. 383, 2320-2332.

Keller, M.D., Harris, K.M., Jensen-Wachspress, M.A., Kankate, V.V., Lang, H., Lazarski, C.A., Durkee-Shock, J., Lee, P.H., Chaudhry, K., Webber, K., et al. 2020. SARS-CoV-2-specific T cells are rapidly expanded for therapeutic use and target conserved regions of the membrane protein. Blood 136, 2905-2917.

Khanolkar, A., Fulton, R.B., Epping, L.L., Pham, N.L., Tifrea, D., Varga, S.M., and Harty, J.T. 2010. T cell epitope specificity and pathogenesis of mouse hepatitis virus-1-induced disease in susceptible and resistant hosts. J. Immunol. 185, 1132-1141.

Körner, R.W., Majjouti, M., Alejandre Alcazar, M.A., and Mahabir, E. 2020. Of mice and men: the coronavirus MHV and mouse models as a translational approach to understand SARS-CoV-2. Viruses 12, 880.

Koutsakos, M., Lee, W.S., Wheatley, A.K., Kent, S.J., and Juno, J.A. 2021. T follicular helper cells in the humoral immune response to SARS-CoV-2 infection and vaccination. J. Leukoc. Biol. doi: 0.1002/JLB.5MR0821-464R.

Laing, A.G., Lorenc, A., Del Barrio, I.D.M., Das, A., Fish, M., Monin, L., Muñoz-Ruiz, M., McKenzie, D.R., Hayday, T.S., FrancosQuijorna, I., et al. 2020. A dynamic COVID-19 immune signature includes associations with poor prognosis. Nat. Med. 26, 1623-1635.

Le Bert, N., Clapham, H.E., Tan, A.T., Chia, W.N., Tham, C.Y.L., Lim, J.M., Kunasegaran, K., Tan, L.W.L., Dutertre, C.A., Shankar, N., et al. 2021. Highly functional virus-specific cellular immune response in asymptomatic SARS-CoV-2 infection. J. Exp. Med. 218, e2020617.

Le Bert, N., Tan, A.T., Kunasegaran, K., Tham, C.Y.L., Hafezi, M., Chia, A., Chng, M.H.Y., Lin, M., Tan, N., Linster, M., et al. 2020. SARS-CoV-2-specific T cell immunity in cases of COVID-19 and SARS, and uninfected controls. Nature 584, 457-462.

Leibowitz, J.L., Srinivasa, R., Williamson, S.T., Chua, M.M., Liu, M., Wu, S., Kang, H., Ma, X.Z., Zhang, J., Shalev, I., et al. 2010. Genetic determinants of mouse hepatitis virus strain 1 pneumovirulence. J. Virol. 84, 9278-9291.

Li, C.K., Wu, H., Yan, H., Ma, S., Wang, L., Zhang, M., Tang, X., Temperton, N.J., Weiss, R.A., Brenchley, J.M., et al. 2008. T cell responses to whole SARS coronavirus in humans. J. Immunol. 181, 5490-5500.

Liao, M., Liu, Y., Yuan, J., Wen, Y., Xu, G., Zhao, J., Cheng, L., Li, J., Wang, X., Wang, F., et al. 2020. Single-cell landscape of bronchoalveolar immune cells in patients with COVID-19. Nat. Med. 26, 842-844.

Liu, G., Carter, B., and Gifford, D.K. 2021. Predicted cellular immunity population coverage gaps for SARS-CoV-2 subunit vaccines and their augmentation by compact peptide sets. Cell Syst. 12, 102-107.

Liu, M.F., Ning, Q., Pope, M., Mosmann, T., Leibowitz, J., Ding, J.W., Fung, L.S., Rotstein, O., Gorczynski, R., and Levy, G.A. 1998. Resistance of naive mice to murine hepatitis virus strain 3 requires development of a Th1, but not a Th2, response, whereas pre-existing antibody partially protects against primary infection. Adv. Exp. 
Med. Biol. 440, 415-423.

Lu, Z., Laing, E.D., Pena DaMata, J., Pohida, K., Tso, M.S., Samuels, E.C., Epsi, N.J., Dorjbal, B., Lake, C., Richard, S.A., et al. 2021. Durability of SARS-CoV-2-specific T cell responses at 12-months post-infection. J. Infect. Dis. 224, 2010-2019.

Lucas, C., Wong, P., Klein, J., Castro, T.B., Silva, J., Sundaram, M., Ellingson, M.K., Mao, T., Oh, J.E., Israelow, B., et al. 2020. Longitudinal analyses reveal immunological misfiring in severe COVID19. Nature 584, 463-469.

Mahmoudi, S., Rezaei, M., Mansouri, N., Marjani, M., and Mansouri, D. 2020. Immunologic features in coronavirus disease 2019: functional exhaustion of T cells and cytokine storm. J. Clin. Immunol. 40, 974-976.

Martin, M.D. and Badovinac, V.P. 2018. Defining memory CD8 T cell. Front. Immunol. 9, 2692.

McMahan, K., Yu, J., Mercado, N.B., Loos, C., Tostanoski, L.H., Chandrashekar, A., Liu, J., Peter, L., Atyeo, C., Zhu, A., et al. 2021. Correlates of protection against SARS-CoV-2 in rhesus macaques. Nature 590, 630-634.

Moderbacher, C.R., Ramirez, S.I., Dan, J.M., Grifoni, A., Hastie, K.M., Weiskopf, D., Belanger, S., Abbott, R.K., Kim, C., Choi, J., et al. 2020. Antigen-specific adaptive immunity to SARS-CoV-2 in acute COVID-19 and associations with age and disease severity. Cell 183, 996-1012.

Muñoz-Fontela, C., Dowling, W.E., Funnell, S.G., Gsell, P.S., RiverosBalta, A.X., Albrecht, R.A., Andersen, H., Baric, R.S., Carroll, M.W., Cavaleri, M., et al. 2020. Animal models for COVID-19. Nature 586, 509-515.

Naeem, Z. 2013. Middle East respiratory syndrome (MERS): an update. Int. J. Health Sci. 7, V-VI. doi:10.12816/0006053.

Neidleman, J., Luo, X., Frouard, J., Xie, G., Gill, G., Stein, E.S., McGregor, M., Ma, T., George, A.F., Kosters, A., et al. 2020. SARSCoV-2-specific T cells exhibit phenotypic features of helper function, lack of terminal differentiation, and high proliferation potential. Cell Rep. Med. 1, 100081.

Neidleman, J., Luo, X., George, A.F., McGregor, M., Yang, J., Yun, C., Murray, V., Gill, G., Greene, W.C., Vasquez, J., et al. 2021. Distinctive features of SARS-CoV-2-specific T cells predict recovery from severe COVID-19. Cell Rep. 36, 109414.

Nelde, A., Bilich, T., Heitmann, J.S., Maringer, Y., Salih, H.R., Roerden, M., Lübke, M., Bauer, J., Rieth, J., Wacker, M., et al. 2021. SARS-CoV-2-derived peptides define heterologous and COVID19-induced T cell recognition. Nat. Immunol. 22, 74-85.

Ng, O.W., Chia, A., Tan, A.T., Jadi, R.S., Leong, H.N., Bertoletti, A., and Tan, Y.J. 2016. Memory T cell responses targeting the SARS coronavirus persist up to 11 years post-infection. Vaccine $\mathbf{3 4}$, 2008-2014.

Nielsen, S.S., Vibholm, L.K., Monrad, I., Olesen, R., Frattari, G.S., Pahus, M.H., Højen, J.F., Gunst, J.D., Erikstrup, C., Holleufer, A., et al. 2021. SARS-CoV-2 elicits robust adaptive immune responses regardless of disease severity. EBioMedicine 68, 103410.

Noh, J.Y., Jeong, H.W., Kim, J.H., and Shin, E.C. 2021. T cell-oriented strategies for controlling the COVID-19 pandemic. Nat. Rev. Immunol. 21, 687-688.

Oh, H.L.J., Chia, A., Chang, C.X.L., Leong, H.N., Ling, K.L., Grotenbreg, G.M., Gehring, A.J., Tan, Y.J., and Bertoletti, A. 2011. Engineering $\mathrm{T}$ cells specific for a dominant severe acute respiratory syndrome coronavirus CD8 T cell epitope. J. Virol. 85, 1046410471.

Painter, M.M., Mathew, D., Goel, R.R., Apostolidis, S.A., Pattekar, A., Kuthuru, O., Baxter, A.E., Herati, R.S., Oldridge, D.A., Gouma S., et al. 2021. Rapid induction of antigen-specific $\mathrm{CD} 4^{+} \mathrm{T}$ cells is associated with coordinated humoral and cellular immunity to SARS-CoV-2 mRNA vaccination. Immunity 54, 2133-2142.

Pan, K., Chiu, Y., Huang, E., Chen, M., Wang, J., Lai, I., Singh, S., Shaw, R.M., MacCoss, M.J., and Yee, C. 2021. Mass spectrometric identification of immunogenic SARS-CoV-2 epitopes and cognate
TCRs. Proc. Natl. Acad. Sci. USA 118, e2111815118.

Peng, G., He, J., Lin, J., Zhou, D., Yu, D., Liang, W., Li, L., Guo, R., Luo, H., and Xu, R. 2003. Epidemiological study on severe acute respiratory syndrome in Guangdong province. Zhonghua Liu Xing Bing Xue Za Zhi 24, 350-352.

Peng, Y., Mentzer, A.J., Liu, G., Yao, X., Yin, Z., Dong, D., Dejnirattisai, W., Rostron, T., Supasa, P., Liu, C., et al. 2020. Broad and strong memory $\mathrm{CD}^{+}$and $\mathrm{CD} 8^{+} \mathrm{T}$ cells induced by SARS-CoV-2 in UK convalescent individuals following COVID-19. Nat. Immunol. 21, 1336-1345.

Peng, H., Yang, L., Wang, L., Li, J., Huang, J., Lu, Z., Koup, R.A., Bailer, R.T., and Wu, C. 2006. Long-lived memory T lymphocyte responses against SARS coronavirus nucleocapsid protein in SARSrecovered patients. Virology 351, 466-475.

Phares, T.W., Stohlman, S.A., Hwang, M., Min, B., Hinton, D.R., and Bergmann, C.C. 2012. CD4 T cells promote CD8 T cell immunity at the priming and effector site during viral encephalitis. J. Virol. 86, 2416-2427.

Pillaiyar, T., Wendt, L.L., Manickam, M., and Easwaran, M. 2021. The recent outbreaks of human coronaviruses: a medicinal chemistry perspective. Med. Res. Rev. 41, 72-135.

Pizzolla, A. and Wakim, L.M. 2019. Memory T cell dynamics in the lung during influenza virus infection. J. Immunol. 202, 374-381.

Rha, M.S., Jeong, H.W., Ko, J.H., Choi, S.J., Seo, I.H., Lee, J.S., Sa, M., Kim, A.R., Joo, E.J., Ahn, J.Y., et al. 2021. PD-1-expressing SARS-CoV-2-specific CD8 ${ }^{+} \mathrm{T}$ cells are not exhausted, but functional in patients with COVID-19. Immunity 54, 44-52.

Rha, M.S. and Shin, E.C. 2021. Activation or exhaustion of CD8 ${ }^{+}$ T cells in patients with COVID-19. Cell. Mol. Immunol. 18, 23252333.

Roukens, A.H.E., Pothast, C.R., König, M., Huisman, W., Dalebout, T., Tak, T., Azimi, S., Kruize, Y., Hagedoorn, R.S., Zlei, M., et al. 2021. Prolonged activation of nasal immune cell populations and development of tissue-resident SARS-CoV-2 specific CD8 ${ }^{+} \mathrm{T}$ cell responses following COVID-19. Nat. Immunol. 23, 23-32.

Rydyznski Moderbacher, C., Ramirez, S.I., Dan, J.M., Grifoni, A., Hastie, K.M., Weiskopf, D., Belanger, S., Abbott, R.K., Kim, C., Choi, J., et al. 2020. Antigen-specific adaptive immunity to SARSCoV-2 in acute COVID-19 and associations with age and disease severity. Cell 183, 996-1012.

Sahin, U., Muik, A., Derhovanessian, E., Vogler, I., Kranz, L.M., Vormehr, M., Baum, A., Pascal, K., Quandt, J., and Maurus, D. 2020. COVID-19 vaccine BNT162b1 elicits human antibody and $\mathrm{T}_{\mathrm{H}} 1 \mathrm{~T}$ cell responses. Nature 586, 594-599.

Saini, S.K., Hersby, D.S., Tamhane, T., Povlsen, H.R., Amaya Hernandez, S.P., Nielsen, M., Gang, A.O., and Hadrup, S.R. 2021. SARS-CoV-2 genome-wide T cell epitope mapping reveals immunodominance and substantial CD8 ${ }^{+} \mathrm{T}$ cell activation in COVID19 patients. Sci. Immunol. 6, eabf7550.

Sariol, A. and Perlman, S. 2020. Lessons for COVID-19 immunity from other coronavirus infections. Immunity 53, 248-263.

Schenkel, J.M. and Masopust, D. 2014. Tissue-resident memory T cells. Immunity 41, 886-897.

Schub, D., Klemis, V., Schneitler, S., Mihm, J., Lepper, P.M., Wilkens, H., Bals, R., Eichler, H., Gärtner, B.C., Becker, S.L., et al. 2020. High levels of SARS-CoV-2-specific T cells with restricted functionality in severe courses of COVID-19. JCI Insight 5, e142167.

Schulien, I., Kemming, J., Oberhardt, V., Wild, K., Seidel, L.M., Killmer, S., Sagar, Daul, F., Salvat Lago, M., Decker, A., et al. 2021. Characterization of pre-existing and induced SARS-CoV-2-specific $\mathrm{CD}^{+}$T cells. Nat. Med. 27, 78-85.

Seder, R.A. and Ahmed, R. 2003. Similarities and differences in CD4 $4^{+}$ and $\mathrm{CD}^{+}$effector and memory T cell generation. Nat. Immunol. 4, 835-842.

Sekine, T., Perez-Potti, A., Rivera-Ballesteros, O., Strålin, K., Gorin, J.B., Olsson, A., Llewellyn-Lacey, S., Kamal, H., Bogdanovic, G., Muschiol, S., et al. 2020. Robust T cell immunity in convalescent 
individuals with asymptomatic or mild COVID-19. Cell 183, 158168.

Sette, A. and Crotty, S. 2021. Adaptive immunity to SARS-CoV-2 and COVID-19. Cell 184, 861-880.

Shomuradova, A.S., Vagida, M.S., Sheetikov, S.A., Zornikova, K.V., Kiryukhin, D., Titov, A., Peshkova, I.O., Khmelevskaya, A., Dianov, D.V., Malasheva, M., et al. 2020. SARS-CoV-2 epitopes are recognized by a public and diverse repertoire of human $\mathrm{T}$ cell receptors. Immunity 53, 1245-1257.

Singer, M., Wang, C., Cong, L., Marjanovic, N.D., Kowalczyk, M.S., Zhang, H., Nyman, J., Sakuishi, K., Kurtulus, S., Gennert, D., et al. 2016. A distinct gene module for dysfunction uncoupled from activation in tumor-infiltrating T cells. Cell 166, 1500-1511.

Song, J.W., Zhang, C., Fan, X., Meng, F.P., Xu, Z., Xia, P., Cao, W.J., Yang, T., Dai, X.P., Wang, S.Y., et al. 2020. Immunological and inflammatory profiles in mild and severe cases of COVID-19. Nat. Commun. 11, 3410.

Swadling, L., Diniz, M.O., Schmidt, N.M., Amin, O.E., Chandran, A., Shaw, E., Pade, C., Gibbons, J.M., Le Bert, N., Tan, A.T., et al. 2021. Pre-existing polymerase-specific T cells expand in abortive seronegative SARS-CoV-2. Nature 601, 110-117.

Swanson, P.A., Padilla, M., Hoyland, W., McGlinchey, K., Fields, P.A., Bibi, S., Faust, S.N., McDermott, A.B., Lambe, T., Pollard, A.J., et al. 2021. T-cell mediated immunity after AZD1222 vaccination: A polyfunctional spike-specific $\mathrm{T}_{\mathrm{H}} 1$ response with a diverse TCR repertoire. Sci. Transl. Med. 13, eabj7211.

Szabo, P.A., Dogra, P., Gray, J.I., Wells, S.B., Connors, T.J., Weisberg, S.P., Krupska, I., Matsumoto, R., Poon, M.M.L., Idzikowski, E., et al. 2021. Longitudinal profiling of respiratory and systemic immune responses reveals myeloid cell-driven lung inflammation in severe COVID-19. Immunity 54, 797-814.

Tan, A.T., Linster, M., Tan, C.W., Le Bert, N., Chia, W.N., Kunasegaran, K., Zhuang, Y., Tham, C.Y.L., Chia, A., Smith, G.J., et al. 2021. Early induction of functional SARS-CoV-2-specific T cells associates with rapid viral clearance and mild disease in COVID-19 patients. Cell Rep. 34, 108728.

Tan, L., Wang, Q., Zhang, D., Ding, J., Huang, Q., Tang, Y.Q., Wang, Q., and Miao, H. 2020. Lymphopenia predicts disease severity of COVID-19: a descriptive and predictive study. Sig. Transduct. Target. Ther. 5, 33.

Tang, F., Quan, Y., Xin, Z.T., Wrammert, J., Ma, M.J., Lv, H., Wang, T.B., Yang, H., Richardus, J.H., Liu, W., et al. 2011. Lack of peripheral memory B cell responses in recovered patients with severe acute respiratory syndrome: a six-year follow-up study. J. Immunol. 186, 7264-7268.

Tarke, A., Sidney, J., Methot, N., Yu, E.D., Zhang, Y., Dan, J.M., Goodwin, B., Rubiro, P., Sutherland, A., Wang, E., et al. 2021. Impact of SARS-CoV-2 variants on the total CD $4^{+}$and $\mathrm{CD} 8^{+} \mathrm{T}$ cell reactivity in infected or vaccinated individuals. Cell Rep. Med. 2, 100355.

Thieme, C.J., Anft, M., Paniskaki, K., Blazquez-Navarro, A., Doevelaar, A., Seibert, F.S., Hoelzer, B., Konik, M.J., Berger, M.M., Brenner, T., et al. 2020. Robust T cell response toward spike, membrane, and nucleocapsid SARS-CoV-2 proteins is not associated with recovery in critical COVID-19 patients. Cell Rep. Med. 1, 100092.

Tian, Y., Babor, M., Lane, J., Schulten, V., Patil, V.S., Seumois, G., Rosales, S.L., Fu, Z., Picarda, G., Burel, J., et al. 2017. Unique phenotypes and clonal expansions of human CD4 effector memory T cells re-expressing CD45RA. Nat. Commun. 8, 1473.

Van Der Hoek, L., Pyrc, K., Jebbink, M.F., Vermeulen-Oost, W., Berkhout, R.J.M., Wolthers, K.C., Wertheim-Van Dillen, P.M.E., Kaandorp, J., Spaargaren, J., and Berkhout, B. 2004. Identification of a new human coronavirus. Nat. Med. 10, 368-373.

Wang, Y., Zhou, Y., Yang, Z., Xia, D., Hu, Y., and Geng, S. 2020. Clinical characteristics of patients with severe pneumonia caused by the SARS-CoV-2 in Wuhan, China. Respiration 99, 649-657.
Weiskopf, D., Schmitz, K.S., Raadsen, M.P., Grifoni, A., Okba, N.M.A., Endeman, H., van den Akker, J.P.C., Molenkamp, R., Koopmans, M.P.G., van Gorp, E.C.M., et al. 2020. Phenotype and kinetics of SARS-CoV-2-specific T cells in COVID-19 patients with acute respiratory distress syndrome. Sci. Immunol. 5, eabd 2071.

Weiss, S.R. and Navas-Martin, S. 2005. Coronavirus pathogenesis and the emerging pathogen severe acute respiratory syndrome coronavirus. Microbiol. Mol. Biol. Rev. 69, 635-664.

Wellington, D., Yin, Z., Kessler, B.M., and Dong, T. 2021. Immunodominance complexity: lessons yet to be learned from dominant T cell responses to SARS-COV-2. Curr. Opin. Virol. 50, 183-191.

Wherry, E.J. and Kurachi, M. 2015. Molecular and cellular insights into T cell exhaustion. Nat. Rev. Immunol. 15, 486-499.

WHO. 2021. WHO Coronavirus (COVID-19) Dashboard. Geneva: World Health Organization, 2020. Available online: https://covid19. who.int/ (last cited: [Nov 29, 2021])

Williamson, J.S. and Stohlman, S.A. 1990. Effective clearance of mouse hepatitis virus from the central nervous system requires both CD4 $4^{+}$and CD8 ${ }^{+}$T cells. J. Virol. 64, 4589-4592.

Yamaguchi, K., Goto, N., Kyuwa, S., Hayami, M., and Toyoda, Y. 1991. Production of mice from a lethal coronavirus infection in the central nervous system by adoptive transfer of virus-specific T cell clones. J. Neuroimmunol. 32, 1-9.

Yang, L.T., Peng, H., Zhu, Z.L., Li, G., Huang, Z.T., Zhao, Z.X., Koup, R.A., Bailer, R.T., and Wu, C.Y. 2006. Long-lived effector/central memory $\mathrm{T}$-cell responses to severe acute respiratory syndrome coronavirus (SARS-CoV) S antigen in recovered SARS patients. Clin. Immunol. 120, 171-178.

Yang, L.T., Peng, H., Zhu, Z.L., Li, G., Huang, Z.T., Zhao, Z.X., Koup, R.A., Bailer, R.T., and Wu, C.Y. 2007. Persistent memory $\mathrm{CD}^{+}$and $\mathrm{CD} 8^{+} \mathrm{T}$-cell responses in recovered severe acute respiratory syndrome (SARS) patients to SARS coronavirus M antigen. J. Gen. Virol. 88, 2740-2748.

Yang, X., Yu, Y., Xu, J., Shu, H., Xia, J., Liu, H., Wu, Y., Zhang, L., Yu, Z., Fang, M., et al. 2020. Clinical course and outcomes of critically ill patients with SARS-CoV-2 pneumonia in Wuhan, China: a singlecentered, retrospective, observational study. Lancet Respir. Med. 8, 475-481.

Yang, J., Zhong, M., Hong, K., Yang, Q., Zhang, E., Zhou, D., Xia, J., Chen, Y.Q., Sun, M., Zhao, B., et al. 2021. Characteristics of T-cell responses in COVID-19 patients with prolonged SARSCoV-2 positivity - a cohort study. Clin. Transl. Immunol. 10, e1259.

Yasui, F., Kai, C., Kitabatake, M., Inoue, S., Yoneda, M., Yokochi, S., Kase, R., Sekiguchi, S., Morita, K., Hishima, T., et al. 2008. Prior immunization with severe acute respiratory syndrome (SARS)associated coronavirus (SARS-CoV) nucleocapsid protein causes severe pneumonia in mice infected with SARS-CoV. J. Immunol. 181, 6337-6348.

Zaki, A.M., van Boheemen, S., Bestebroer, T.M., Osterhaus, A.D.M.E., and Fouchier, R.A.M. 2012. Isolation of a novel coronavirus from a man with pneumonia in Saudi Arabia. N. Engl. J. Med. 367, 1814-1820.

Zhang, S., Asquith, B., Szydlo, R., Tregoning, J.S., and Pollock, K.M. 2021. Peripheral T cell lymphopenia in COVID-19: potential mechanisms and impact. Immunother. Adv. 1, ltab015.

Zhao, J., Li, K., Wohlford-Lenane, C., Agnihothram, S.S., Fett, C., Zhao, J., Gale, M.J., Baric, R.S., Enjuanes, L., Gallagher, T., et al. 2014. Rapid generation of a mouse model for Middle East respiratory syndrome. Proc. Natl. Acad. Sci. USA 111, 4970-4975.

Zhao, Z., Zhang, F., Xu, M., Huang, K., Zhong, W., Cai, W., Yin, Z., Huang, S., Deng, Z., Wei, M., et al. 2003. Description and clinical treatment of an early outbreak of severe acute respiratory syndrome (SARS) in Guangzhou, PR China. J. Med. Microbiol. 52, $715-720$.

Zhao, J., Zhao, J., and Perlman, S. 2010. T cell responses are required for protection from clinical disease and for virus clearance in se- 
vere acute respiratory syndrome coronavirus-infected mice. $J$. Virol. 84, 9318-9325.

Zheng, M., Gao, Y., Wang, G., Song, G., Liu, S., Sun, D., Xu, Y., and Tian, Z. 2020b. Functional exhaustion of antiviral lymphocytes in COVID-19 patients. Cell. Mol. Immunol. 17, 533-535.

Zheng, H.Y., Zhang, M., Yang, C.X., Zhang, N., Wang, X.C., Yang, X.P., Dong, X.Q., and Zheng, Y.T. 2020a. Elevated exhaustion levels and reduced functional diversity of $\mathrm{T}$ cells in peripheral blood may predict severe progression in COVID-19 patients. Cell. Mol. Immunol. 17, 541-543.
Zhou, Z., Qiu, Y., and Ge, X. 2021. The taxonomy, host range and pathogenicity of coronaviruses and other viruses in the Nidovirales order. Animal Diseases 1, 5.

Zhou, P., Yang, X.L., Wang, X.G., Hu, B., Zhang, L., Zhang, W., Si, H.R., Zhu, Y., Li, B., Huang, C.L., et al. 2020. A pneumonia outbreak associated with a new coronavirus of probable bat origin. Nature 579, 270-273.

Zhuang, Z., Lai, X., Sun, J., Chen, Z., Zhang, Z., Dai, J., Liu, D., Li, Y., Li, F., Wang, Y., et al. 2021. Mapping and role of T cell response in SARS-CoV-2-infected mice. J. Exp. Med. 218, e20202187. 